\author{
Law \& Economics Working Papers \\ Law \& Economics Working Papers Archive: \\ 2003-2009 \\ University of Michigan Law School \\ Year 2004
}

\title{
International Tax as International Law
}

Reuven S. Avi-Yonah

University of Michigan Law School, aviyonah@umich.edu 


\title{
UNIVERSITY OF MICHIGAN
}

JOHN M. OLIN CENTER FOR LAW \& ECONOMICS

\author{
INTERNATIONAL TAX \\ AS INTERNATIONAL LAW
}

REUVEn AvI-YoNAH

PAPER \#04-007

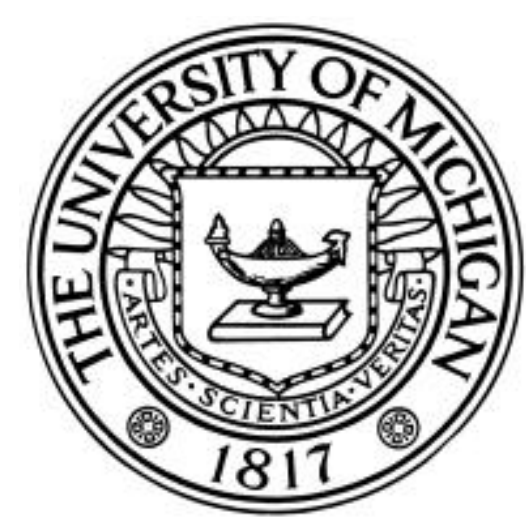

THIS PAPER CAN BE DOWNLOADED WITHOUT CHARGE AT:

Michigan John M. Olin Website

HTTP:/WWW.LAW.UMICH.EDU/CENTERSANDPROGRAMS/OLIN/PAPERS.HTM 


\section{INTERNATIONAL TAX AS INTERNATIONAL LAW \\ Reuven S. Avi- Yonah ${ }^{1}$}

\section{Introduction: Is International Tax Law Part of International Law?}

To an international lawyer, the question posed above probably seems ridiculous. $O f$ course international tax law is part of international law, just like tax treaties are treaties. But to an international tax lawyer, the question probably seems less obvious, because most international tax lawyers do not think of themselves primarily as international lawyers (public or private), but rather as tax lawyers who happen to deal with cross-border transactions. And indeed, once we delve into the details, it becomes clear that in some ways international tax law is different from "regular" international law. For example, international tax lawyers talk about residence and source jurisdiction, not nationality and territoriality- and as we shall see, the different names also carry different content. And while tax treaties are indeed treaties, they are concluded differently than other treaties (e.g., they are negotiated by the Treasury, not the State Department), are subject to different modes of interpretation (the Vienna Convention on the Law of Treaties ("VCLT"), the "Bible" of the international lawyer, is rarely invoked), and in the United States are subject to a rather peculiar mode of unilateral change, the treaty override.

The purpose of this article is to introduce to the international lawyer the somewhat different set of categories employed by international tax lawyers, and explain the

\footnotetext{
${ }^{1}$ Irwin I. Cohn Professor of Law, the University of Michigan. I would like to thank Eyal Benvenisti, Yariv Brauner, Steve Ratner, Mathias Reimann, and Joel Samuels for their helpful comments.
} 
reasons for some of the differences. At the same time, I hope to persuade practicing international tax lawyers and international tax academics that their field is indeed part of international law, and that it would help them to think of it this way. For example, I believe that knowledge of the VCLT would help international tax lawyers in interpreting tax treaties, and avoid some common mistakes.

This article is divided into five parts. After this introduction, Part 2 discusses international jurisdiction to tax and how it differs from traditional international law concepts of jurisdiction. The issues addressed in this Part are familiar to international tax lawyers but may be new and interesting for international lawyers. Part 3 discusses tax treaties and how they differ from regular treaties in both interpretation and modification. Here, international tax lawyers can learn from international lawyers, but also vice versa. Part 4 discusses the difficult and much debated question whether there exists an international customary tax law. In this context it is international tax lawyers who have most to gain by listening to international lawyers. Part 5 concludes by returning to the question posed above, answering in the affirmative, and then summarizing the ways international tax lawyers and international lawyers can learn from each other.

\section{Jurisdiction to Tax.}

The traditional grounds of jurisdiction to prescribe in international law are nationality ("the activities, interest, status or relations of [a state's] nationals outside as well as 
within its territory") and territoriality ("conduct that, wholly or in substantial part, takes place within [a state's] territory"). ${ }^{2}$ Territoriality is expanded to cover conduct outside a state's territory that has, or is intended to have, a "substantial effect" within its territory. As we shall see, international tax law modifies both concepts to a significant extent, resulting primarily in expanding the scope of nationality jurisdiction.

a. Individuals: Redefinition of Natio nality Jurisdiction as Residence.

Nationality is usually understood as equivalent to citizenship. However, except for the United States, almost no other country in the world claims the right to tax its citizens on foreign source income when they live permanently in another country. The United States insists on the right to tax its citizens on worldwide income no matter where they live. ${ }^{3}$ This was upheld by the Supreme Court in Cook v. Tait because of the benefits the US provides its citizens even if they live overseas. ${ }^{4}$ But the opinion is weak, its underlying rationale is doubtful (are these benefits really so great?) and almost no other country follows the rule. Thus, although international law seems to sanction the US practice (and the US has written it into all its tax treaties), it seems a dubious rule to follow, and it has been criticized by academics.

Instead, every country in the world (including the United States) has adopted a definition of nationality for tax purposes that is much broader than how nationality is

\footnotetext{
${ }^{2}$ Rest. $3^{\text {rd }}$ Foreign Relations Law U.S. sec. 402.

${ }^{3}$ See Internal Revenue Code of 1986 (IRC) sec. 1, 2(d), 7701(a)(30).

${ }^{4} 265$ US 47 (1924).
} 
commonly understood. That definition is residence, which usually implies mere physical presence in the country for a minimum number of days. In the U.S., physical presence for 183 days in a given year is generally sufficient to subject an individual to taxing jurisdiction on her world-wide income for that year. ${ }^{5}$ Even fewer days suffice if added to days spent in the U.S. in the previous two years. Other countries follow a similar rule, although they sometimes supplement it with a "fiscal domicile" test that looks to less bright line factors such as location of principal abode, family ties, and the like. The two tests (physical presence and fiscal domicile) are also incorporated into tax treaties.

This definition is a remarkable expansion of the concept of nationality. I doubt there is another substantive area of international law in which nationality jurisdiction for individuals rests on so flimsy a ground as mere physical presence. In fact, because of this expansive view, it is easy to be subject to residence-based taxation by a country in one year and not in the next, and it is also easy for individuals to have dual tax residency. Elaborate rules are needed to address situations in which individuals move in and out of resident status from year to year (e.g., rules on deemed sales of their property when they leave), and to avoid dual residence double taxation.

Why has nationality based jurisdiction been so expanded in tax law? The reason is easy to see if one considers the implications of the relative ease of acquiring a tax haven nationality. If tax law followed the general international law rule and imposed world-wide taxation only on citizens, then a lot of U.S. citizens would acquire

\footnotetext{
${ }^{5}$ IRC 7701(a)(30), 7701(b).
} 
citizenship in some Caribbean tax haven jurisdiction and thereby avoid taxation on their foreign source income while living permanently in the United States. In general, living in a country for over half a year is considered a sufficient ground for worldwide taxation because of the presumed benefits derived from that country.

The residence rule is so widely followed and incorporated into so many treaties that it can be considered part of customary international law, even though it seems contrary to widely shared understandings of nationality (see part 4 below). It is thus appropriate for the United States to follow this rule. It is doubtful, however, whether the U.S. should continue to insist on taxing its citizens living overseas, especially since because of a combination of exemptions and credits (and enforcement difficulties) it collects little tax from them.

\section{b. Corporations: Expansion of Nationality Jurisdiction to CFCs.}

The nationality of corporations is a thorny issue, which comes up in other areas of the law as well. In general, corporations are considered nationals based either on the country in which they are incorporated (the U.S. approach), or the country from which they are managed and controlled (the U.K. approach), or both. Each approach has its advantages and disadvantages; the U.S. approach is the easiest to administer but also the most manipulable, as shown recently by so-called "inversion" transactions in which corporations shifted their nominal country of incorporation to Bermuda while retaining all of their headquarters and management in the United 
States. The U.K. approach is less easily manipulated but requires more administrative resources to police.

The interesting aspect of nationality jurisdiction for corporations in tax law is the gradual adoption of a rule that permits countries to tax "controlled foreign corporations" (CFCs), i.e., corporations controlled by nationals, as if they were nationals themselves. This rule originated with the United States. Because the definition of corporate nationality in the U.S. is formal (country of incorporation), it is easy for U.S. nationals (residents) who have foreign source income to avoid taxation on such income by shifting it to a corporation incorporated in another country, preferably a tax haven, where it can accumulate tax free. For example, Jacob Schick, the inventor of the Schick disposable razor, transferred his patent to it to a Bermuda corporation which accumulated the royalties; Schick later proceeded to retire to Bermuda, gave up his US citizenship, and lived on the accumulated tax-free profits.

To address this problem, the US adopted in 1937 a rule which taxed shareholders in "foreign personal holding corporations" (FPHCs). FPHC was defined as a foreign corporation controlled (over $50 \%$ by vote) by five or fewer U.S. resident individuals, and whose income was over $60 \%$ passive (since passive income was considered easier to shift than active income). Interestingly, at the time, the US considered it a breach of international law to tax a FPHC (a foreign national) directly on foreign source income; instead, it adopted a rule that taxed the US shareholders on a deemed 
dividend of the accumulated passive income of the FPHC. This rule can be compared to the personal holding company (PHC) regime adopted at the same time, which applied to domestic corporations and taxed them directly on their accumulated income at the shareholder rate (PHCs were used by shareholders to shelter US source income from the higher individual rate by earning the income through a corporation subject to tax at a lower rate).

The deemed dividend rule was upheld by Judge Frank of the Second Circuit without paying any attention to its international law implications. ${ }^{6}$ And yet, it clearly represented a major expansion of US residence taxing jurisdiction, since taxing a deemed dividend is economically equivalent to taxing a foreign corporation directly on foreign source income. It could certainly be argued in 1943 that this rule was a breach of international law, just like Judge Hand's Alcoa decision (1945), which invented the effects doctrine, was likewise arguably a breach of international law.

The impact of the deemed dividend rule was greatly expanded when the Kennedy administration decided in 1961 to propose applying the same rule to all income of corporations that are over $50 \%$ controlled by large (10\% by vote each) US shareholders, i.e., to subsidiaries of US multinationals (CFCs). Ultimately, this resulted in the enactment in 1962 of "Subpart F" which applied the deemed dividend rule to certain types of income (mostly passive income) of all CFCs. ${ }^{7}$

${ }^{6}$ Eder v. Commissioner, 138 F.2d 27 (1943).

${ }^{7}$ IRC sections 951-960. 
Again, there was no international law challenge to the deemed dividend rule. Instead, other countries began to copy the CFC regime: Germany (1972), Canada (1975), Japan (1978), France (1980), the UK (1984). Currently, there are 23 countries with CFC rules (mostly developed ones), and the number is likely to increase. Thus, it would seem that the CFC concept has arguably become part of customary international law, just like the expansion of territorial jurisdiction over international waters rapidly changed international law from the 1970s onward.

Even more striking is the fact that many of the countries adopting the $\mathrm{CFC}$ rule abandoned the deemed dividend idea, which can lead to significant difficulties in practice, in favor of direct taxation of the CFC- i.e., direct taxation of a foreign corporation on foreign source income just because it is controlled by residents. See, e.g., Sweden, France. Thus, the jurisdictional rule has been changing and no longer seems to require a deemed dividend. Indeed, the IRS itself has adopted this view, because it now believes that the PHC regime, as well as the older accumulated earnings tax regime, both apply directly to foreign corporations even though their effect is to tax the corporation on foreign source income. This is particularly striking for PHCs, because it was so clear in 1937 that the U.S. had no jurisdiction to tax foreign corporations on foreign source income that Congress did not bother to specify that a PHC could not be a foreign corporation (while at the same time adopting the parallel FPHC regime explicitly for foreign corporations). Now this oversight enables the IRS to argue that under the new understanding of jurisdictional limits, the PHC rules as well as the FPHC rules apply to foreign corporations. 
Claiming that nationality jurisdiction applies to foreign corporations just because they are controlled by nationals is a striking departure from ordinary international law. Compare, for example, the oft recurring disputes about the extraterritorial application of international sanctions. In both the Fruehauf (1965) and Sensor (1982) cases, the foreign courts explicitly rejected U.S. claims to require foreign subsidiaries of US multinationals to obey US sanctions aimed at China and the USSR, respectively. In Sensor, the Dutch court went through all the possible grounds for jurisdiction and explicitly found that none applied. It was clear that nationality jurisdiction did not apply even though the subsidiary was controlled from the United States.

What, then, enables the United States and other countries to expand nationality jurisdiction to subsidiaries in the tax area? The explanation is the "first bite at the apple rule", adopted by the League of Nations in 1923. Under that rule, the source (territorial) jurisdiction has the primary right to tax income arising within it, and the residence (nationality) jurisdiction is obligated to prevent double taxation by granting an exemption or a credit. Thus, permitting the expansion of residence jurisdiction to CFCs does not harm the right of source jurisdictions to tax them first; residence (nationality) jurisdiction only applies as a residual matter when the source jurisdiction abstains from taxing. This still leads sometimes to complaints by source jurisdictions that the residence jurisdiction is taking away their right to effectively grant tax holidays to foreign investors, but even that is mitigated by the restricted application of CFC rules to passive income. 
In general, I believe this story is a good illustration of the growth of customary international law in the tax area. In the 1930-1960s period, there was a clear rule of customary international law that prohibited taxing foreign corporations on foreign source income. That rule was universally observed and was considered binding, as illustrated by the US avoiding an outright breach through the deemed dividend mechanism. However, once a lot of countries changed the rule by taxing CFCs directly, the US did not consider it binding any more, as indicated by applying the PHC regime to foreign corporations. The next step for the US, as advocated by many, would be to abolish the obsolete deemed dividend rule and replace it by a direct tax on the CFCs.

\section{c. The Problem of Territorial Jurisdiction (Source).}

The right of countries to tax income arising in their territory is well established in international law. In fact, some countries (e.g., France) begin with the assumption that the only income they have the right to tax is domestic source income, although France and other territorial jurisdictions have long since begun to tax some income of nationals from foreign sources. And even countries that begin with worldwide taxation of nationals, like the US and the UK, in practice do not tax as heavily foreign source income. 
The special problem of territoriality in the tax area is that the source of income is very difficult to define. In fact, most public finance economists would deny that it is a meaningful concept in the majority of cases. Think of a law firm in country A that provides advice on the legal implications of a merger of two multinationals whose parents are in countries A and B and whose operations are in twenty countries around the globe. What is the economic source of the law firm's income?

Ideally, one could imagine a world in which all countries tax only on a nationality (residence) basis, and the only problem would be assigning residence to individuals (not too hard) and to corporations (quite difficult). But in practice, as long as countries desire to tax non-residents on domestic source income, as they have every right to do under international law, the problem of defining source would persist.

To some extent the problem has been solved by arbitrary rules embodied in tax treaties (and that in my view may form part of customary international law) that define the source of various categories of income. For example, income from services is sourced where the services are provided (and not where they are consumed); dividend and interest income are sourced by the residence of the payor; capital gains are sourced by the residence of the seller; and so on. The difficulty then becomes deciding which category income falls into, which is sometimes very hard (consider for example how to distinguish between sales, services and royalty income when downloading software off the internet, buying it in a store, or receiving it in a preinstalled package on a PC). 
In the case of multinationals, the sourcing issue becomes even harder because taxing them requires allocating the income of a controlled group of corporations among taxing jurisdictions. If tax authorities merely followed the form (regarding which subsidiary nominally earned the income from inter-group transactions), all income of multinationals would be booked in tax haven subsidiaries. A whole branch of tax law called transfer pricing is devoted to resolving this problem. In Part 4, I will return to this point, because it provides a good illustration of customary international tax law.

The main point here is simply that territoriality, which is a relatively easy concept to define in international law in general, becomes very hard when tax law is concerned. And it may be a pity that international law makes it so easy to tax foreigners on a territoriality basis, although as long as we want to tax corporations, I suspect that source-based taxation is inevitable (since the residence of corporations is inherently more manipulable and less meaningful than the residence of individuals).

3. Tax Treaties.

a. Treaty Interpretation and the VCLT.

Tax treaties are, of course, treaties: They are considered by the Senate Foreign Relations Committee (and not the Finance Committee) and ratified by the Senate just like any other treaty. But they are also unlike other treaties. First, they are 
negotiated by the International Tax Counsel in the Treasury's Office of Tax Policy, not by the State Department. Second, their interpretation is governed primarily by the Technical Explanation, which is likewise drafted by the Treasury and not by State. And finally, the ways tax treaties are interpreted differ markedly from the interpretation of other treaties.

The biggest difference relates to the role of the VCLT. Bederman writes that "[t]he VCLT is, quite literally, a treaty on treaties. Almost every question of treaty law is settled in that document, and it is an essential bit of reading for every international lawyer." ${ }^{8}$ But not for the international tax lawyer. A search of the tax cases database in LEXIS revealed among hundreds of treaty interpretation cases only one quite recent case in which a court discussed the potential application of the VCLT. ${ }^{9}$

It is true, of course, that the United States signed but never ratified the VCLT; but this does not prevent American international lawyers from relying on it in non-tax contests as embodying customary international law (in fact, having signed the VCLT, the US is supposed not to act contrary to it, VCLT Art. 18). Rather, the lack of reference to the VCLT in tax treaty cases simply results from the fact that most tax lawyers have never heard of it. Instead, they rely for example on the

\footnotetext{
${ }^{8}$ David J. Bederman, International Law Frameworks (2001), 26.
}

${ }^{9}$ Kappus v. Commissioner, 337 F.3d 1053 (DC Cir. 2003). 
OECD commentary on the OECD model tax treaty, which is frequently cited in treaty interpretation cases. ${ }^{10}$

This can sometimes lead to unfortunate, even bizarre, results. For example, VCLT Art. 31 states a general rule that treaties should be interpreted "in good faith in accordance with the ordinary meaning to be given to the terms of the treaty in their context and in light of its object and purpose". "Context" for this purpose includes any subsequent protocols and contemporaneous instruments relating to the treaty, and subsequent practice relating to implementation. VCLT Art. 32 states that as supplementary sources recourse may be had to "preparatory work of the treaty and the circumstances of its conclusion", but only "to confirm the meaning resulting from the application of article 31 " or to "determine the meaning when interpretation according to article 31 (a) leaves the meaning ambiguous or obscure; or (b) leads to a result which is manifestly absurd or unreasonable."

Now consider the case of Xerox Corporation v. United States. ${ }^{11}$ That case involved a highly technical question on the interpretation of the 1975 US-UK tax treaty. As the Court of Claims saw it, the IRS view of the matter was supported by (a) the language of the treaty itself, (b) the contemporaneous technical explanation, (c) IRS practice as evidenced by a Revenue Procedure, and (d) a subsequent agreement between the competent authorities designed to settle the

${ }^{10}$ See, e.g., Taisei Fire and Marine Insurance Co. v. Commissioner, 104 TC 535 (1995).

1141 F.3d 647 (Fed. Cir. 1994). 
matter. Instead, the Court of Appeals chose to ignore all of those sources and rely instead on affidavits submitted to it by the treaty negotiators as to what they meant. It is hard to imagine such a result under the VCLT, since all the Art. 31 sources supported the IRS and the affidavits (at best Art. 32, and therefore inferior, sources) were not even contemporaneous with the treaty but executed years later when the affiants were in private practice and had no stake in protecting the fisc. Not surprisingly, it is hard to defend the result in Xerox from a pure tax perspective either; the general consensus is that the corporation "got away with murder".

My point here is simply that it would be a good idea for international tax lawyers to study the VCLT. A lot of hard thinking went into that treaty, and it should not lightly be ignored.

\section{b. Treaty Overrides.}

The most notorious difference between tax treaties and other US treaties is the frequency of treaty overrides (other treaties are overridden, but much less frequently). Under international law, pacta sunt servanda; "Every treaty in force is binding upon the parties and must be performed by them in good faith" (VCLT Art. 26). "A party may not invoke the provisions of its internal law as justification for its failure to perform a treaty". VCLT Art. 27. 
Under U.S. law, however, treaties are under the Supremacy Clause of the constitution equal in standing to regular laws. Therefore, at least as interpreted by the Supreme Court, the general rule of later in time controls. ${ }^{12}$ In the tax context this rule has been embodied in IRC 7852(d), which states that "[f]or purposes of determining the relationship between a provision of a treaty and any law of the United States affecting revenue, neither the treaty nor the law shall have preferential status by reason of its being a treaty or law."

Of course, this unique US interpretation applies to all US treaties, not just to tax treaties. But at least in recent years, its clearest manifestation has been in the tax area. The reason that tax is particularly sensitive in this context is first, that tax law changes all the time while treaties are slow to renegotiate, and second, that the US House of Representatives has a special role to play in the tax area (all revenue measures must originate with it), but is excluded from involvement with treaties, and therefore insists on its right to change tax treaties through legislation even though this clearly violates customary international law as embodied in the VCLT.

But the interesting question is, when does the US resort to treaty overrides? The answer is rarely, and that when it does so deliberately, an argument can be made that it is justified in doing so. Consider three recent cases from the period 1986-

\footnotetext{
${ }^{12}$ Whitney v. Robertson, 124 US 190, 19495 (1888); Breard v. Greene, 523 US 371, 376 (1998).
} 
1997: the branch profits tax, the earnings stripping rule, and the reverse hybrid rule. $^{13}$

The branch profits tax (BPT) was enacted in 1986 to equalize the position of foreign investors who operate in the US through a subsidiary and through a branch. Before 1986, investors who operated through a subsidiary were subject to tax on the subsidiary's income and also to a withholding tax on dividends, whereas investors who operated through a branch were only subject to a tax on the branch income because distributions from the branch were not a dividend and not subject to withholding tax. Under the branch profit tax, distributions from a branch were made subject to withholding tax. But a problem arose: Many US tax treaties forbad taxing distributions from foreign corporations resident in a treaty country to their foreign shareholders even if the distribution came out of earnings of a US branch, and arguably the branch profits tax violated the spirit of this rule (although not its letter). So did the US resort to treaty override? It did not. Instead, it announced that the BPT will not apply to residents of those treaty countries until the treaties were renegotiated to permit the BPT. In fact, by now most US treaties have been so renegotiated, and other countries (e.g., Germany) have adopted the BPT in their own laws.

But this left the US in a difficult position, because while treaties were slowly renegotiated, it could collect the BPT on some branches but not on others. At the time, there were no limitation on benefits provisions in US treaties, leading to a

${ }^{13}$ IRC sections $884,163(\mathrm{j})$ and $894 \odot$. 
concern that there would be widespread treaty shopping (i.e., setting up a corporation in a treaty jurisdiction just to benefit from the treaty). So the US inserted a limitation on benefits provision into the BPT rule in the Code and made that an explicit treaty override. Was it justified? I believe that an underlying assumption of treaties is that they are only intended to benefit bona fide residents (otherwise, any treaty becomes a "treaty with the world"). Thus, I think the override was justified because it is consistent with the underlying purpose of the treaties. But countries like the Netherlands that later negotiated much longer limitation on benefits provisions that were full of loopholes may have had reason to be miffed, because they derive revenue by letting their treaties be used for treaty shopping.

Next, consider the earnings stripping rule, adopted in 1989. That rule is a "thin capitalization" provision, i.e., it is intended to prevent foreign parents from eliminating the tax base of their US subsidiaries (or branches) through interest deductions by capitalizing them mostly with debt rather than equity. When the rule was adopted the US was very worried it will appear to be a violation of the non-discrimination provision in tax treaties if it applied only to foreign related parties. Thus, to avoid even the appearance of a treaty override, the US instead applied the rule to all "tax exempt related parties", i.e., to domestic tax exempts as well as foreigners. But this was an obvious ruse, since no domestic tax exempts are ever related (i.e., control over 50\%) to domestic taxable subsidiaries. Nor do I believe the ruse was necessary, because in fact most countries have a thin 
capitalization rule and apply it explicitly to foreigners. I thus believe thin capitalization is an accepted customary international law exception to nondiscrimination, which is necessary because the source country has the primary right to tax active business income and without thin capitalization that base can easily disappear. What is striking, though, is how reluctant the US was to override treaties.

Finally, consider the reverse hybrid rule, adopted by the US as a treaty override in 1997. The rule was adopted in response to a transaction in which a Canadian parent set up a limited liability company (LLC) in the US and capitalized it with what was for Canadian purposes equity but for US purposes was treated as debt. The LLC was treated as a branch by the US but as a subsidiary by Canada. The result was that from a US perspective the tax on the branch was offset by interest deductions on the debt with a reduced rate of withholding tax under the treaty, but from a Canadian perspective the income was treated as exe mpt dividends from a controlled subsidiary. Hence double non-taxation. The US could have (and indeed later did) renegotiate the treaty, but this takes time, and a lot of revenue was being lost. Hence the treaty override, which Canada did not object to, which denied treaty benefits to such a "reverse hybrid". Fundamentally, I believe the override was justified because the purpose of tax treaties is to prevent double taxation and not enable double non-taxation; reductions of tax at source should be premised on taxation by the residence jurisdiction. 
So in all of these cases I think an override was justified. The reality is that tax law and practice change too fast to wait for treaties to be renegotiated. Still, overrides should be used sparingly and only when consistent with the underlying purpose of the treaty. And there are unjustified overrides, such as the provision of the alternative minimum tax (AMT) that limits the foreign tax credit to $90 \%$. That leads directly to double taxation and is not justifiable in the treaty context, but courts (including recently the Kappus court) have accepted it as a valid override (even though Congress did not explicitly designate it as such).

\section{Is There A Customary International Tax Law?}

Customary international law is law that "results from a general and consistent practice of states followed by them from a sense of legal obligation."14 "International agreements create law for states parties thereto and may lead to the creation of customary international law when such agreements are intended for adherence by states generally and are in fact widely accepted."15

There clearly are international tax practices that are widely followed, such as for example avoiding double taxation by granting an exemption for foreign source income or a credit for foreign taxes. Moreover, there are over 2,000 bilateral tax treaties in existence, and they all follow one of two widely accepted models (the OECD and UN model treaties), which themselves are quite similar to each other

\footnotetext{
${ }^{14}$ Rest. $3^{\text {rd }}$ (For. Rel.) sec. 102(2).

${ }^{15}$ Rest. $3^{\text {rd }}$ (For. Rel.) sec. 102(3).
} 
and are "intended for adherence by states generally." Is this enough to create a customary international tax law?

This question is hotly debated among international tax lawyers, although it is not usually couched in these terms. Instead, the debate is about whether countries are bound by an "international tax regime" or "international tax system", or whether international tax is only about the law adopted by each country and the treaties it binds itself with. Specifically, the debate is about international tax arbitrage, i.e., transactions that utilize differences between tax laws to achieve double nontaxation. On the one side are those who argue that there is nothing wrong with tax arbitrage since there is no "international tax regime" and each country is free to do as it likes, so taxpayers are also free to exploit differences. On the other hand are those who argue that countries are not so free and that a coherent international tax regime does exist. The debate is in part about specific provisions in US law that are designed to prevent double non-taxation, such as the dual consolidated loss rules (which prevent taxpayers from claiming the same loss to offset income in two taxing jurisdictions). If there is no international tax regime, such rules make no sense. Similarly, rules such as those promulgated by the Treasury in 1998, which prevent taxpayers from using tax arbitrage to reduce foreign taxes, are very controversial.

In the following, I will briefly survey some examples that in my opinion strengthen the view that an international tax regime does exist and that it rises to 
the level of customary international law. As usual, the hard question is whether countries not only follow a rule, but do so out of a sense of legal obligation (opinio juris).

a. Jurisdiction to Tax.

Can a country simply decide to tax non-residents that have no connection to it on foreign source income? The answer is clearly no, both from a practical perspective and, I would argue, from a customary international law perspective. The fact that this rule is followed from a sense of legal obligation is illustrated by the behavior of the US in adopting the FPHC and CFC rules described above. The deemed dividend rule was adopted precisely because the US felt bound by a customary international law rule not to tax non-residents directly on foreign source income, even though they are controlled by residents. The US no longer feels bound by this rule, but that is because enough other countries have adopted CFC legislation that expands the definition of nationality that customary international law has changed. The spread of CFC legislation is a good example of how rapidly customary international law can in fact change.

b. Non-discrimination.

The non-discrimination norm (i.e., that non-residents from a treaty country should not be treated worse than residents) is embodied in all tax treaties. But is it part of 
customary international law? The behavior of the US in the earnings stripping episode suggests that the US felt at the time that the non-discrimination norm was binding even outside the treaty context. Otherwise, even if it did not wish to override treaties, it could have applied a different rule to non-treaty country residents (as it did in the branch profits tax context three years earlier). Thus, I would argue that the non-discrimination norm may in fact be part of customary international law even in the absence of a treaty.

c. The Arm's Length Standard.

The standard applied in all tax treaties to the transfer pricing problem of determining the proper allocation of profits between related entities is the "arm's length standard", which means that transactions between related parties may be adjusted by the tax authorities to the terms that would have been negotiated had the parties been unrelated to each other. This standard has been the governing rule since the 1930 s.

In the 1980s, the US realized that in many circumstances it is very difficult to find comparable transactions between unrelated parties on which to base the arm's length determination. It therefore began the process of revising the regulations that govern transfer pricing. This culminated in 1995 with the adoption of two new methods, the comparable profit method and profit split method, that rely 
much less on finding comparables (and in the case of profit split sometimes require no comparables at all).

What is remarkable about the process by which these regulations were adopted is the US insistence throughout that what it was doing was consistent with the arm's length standard. It even initially called profit split the "basic arm's length return method." But as I have pointed out elsewhere, once you abandon the search for comparables, it is meaningless to call a method "arm's length", because without comparables nobody can know what unrelated parties would have done.

Nevertheless, despite initial objections, the OECD ultimately came to accept the gist of the new methods in its revised transfer pricing guidelines, which were issued a short time after the new US regulations and represent the widely followed consensus view of transfer pricing. The new methods are thus accepted under the rubric of "arm's length".

As Brian Leppard has suggested, the US insistence that it was following the arm's length standard indicates that it felt that the standard is part of customary international law. ${ }^{16}$ Such a finding has important implications because the US states explicitly follow a non-arm's length method, formulary apportionment, which has been twice upheld by the US Supreme Court. If the arm's length method is customary international law, these cases may have been wrongly

\footnotetext{
${ }^{16}$ Brian Leppard, Is the United States Obligated to Drive on the Right? 10 Duke J. Comp. \& Int'1 L. 43 (2000).
} 
decided, as customary international law is part of federal law and arguably preempts contrary state law.

d. Foreign Tax Credits vs. Deductions.

Many economists argue that count ries should only give a deduction for foreign taxes rather than a credit. However, countries generally grant either an exemption for foreign source income or a credit for foreign taxes paid. Remarkably, in most cases (following the lead of the US) this is done even in the absence of a treaty. It is likely that at this point countries consider themselves in practice bound by the credit or exemption norm, and a country would feel highly reluctant to switch to a deduction method instead. Thus, arguably preventing double taxation through a credit or exemption has become part of customary international law.

\section{e. Conclusion.}

If customary international tax law exists, this has important implications for the US and other countries. As Justice Gray wrote 103 years ago in the Paquete Habana case, "[I]nternational law is part of our law, and must be ascertained and administered by the courts of justice of appropriate jurisdiction as often as questions of right depending upon it are duly presented for their determination. For this purpose, where there is no treaty and no controlling executive or legislative act or judicial decision, resort must be had to the customs and usages 
of civilized nations." 17 To the extent legislation exists, it can in the US override customary international law as well as treaties. But in the absence of treaties or legislation, resort can be had to customary international law; and I would argue that it can also be used to ascertain the underlying purposes of treaties.

To the extent that customary international tax law exists, this suggests that it is a mistake to deny the existence of an international tax system or regime. Admittedly, even if an international tax regime exists, it does not follow what we should do about it- this has to be investigated in each particular case. But we should not pretend that there are no binding, widely accepted international tax norms that we should flout only when significant national interests are at stake.

5. Conclusion.

Clearly, international tax law is part of international law, even if it differs in some of its details from generally applicable international law. I believe both international lawyers and international tax lawyers can benefit from viewing international tax law in this way. For international lawyers, the tax field is an interesting arena to test some of their ideas. It offers them a different view of nationality and territoriality jurisdiction, which can perhaps be profitably carried over into other fields (I believe it would help, for example, to take control generally into account in determining the nationality of corporations). It also offers interesting examples of how customary international law can change

${ }^{17} 175$ US 677, 700 (1900). 
rapidly, as in the CFC case. Finally, it suggests that even a basic rule like pacta sunt servanda may sometimes have its exceptions if one wishes to preserve the rationale of the underlying treaty.

I believe, however, that it is international tax lawyers who can benefit the most from viewing their field as part of international law. For example, knowing the VCLT can prevent mistakes such as those committed in Xerox. And understanding that international tax law can be seen in significant part as customary international law can help clarify some of the constraints facing a country like the US as it struggles to adapt its international tax laws to the business realities of the $21^{\text {st }}$ century. 